\title{
Manoeuvring Strategically with Praeteritio
}

\author{
A. Francisca Snoeck Henkemans
}

(C) The Author(s) 2009. This article is published with open access at Springerlink.com

\begin{abstract}
This paper investigates the role that the stylistic device of praeteritio (or paralipsis) can play in arguers' attempts to reconcile their rhetorical with their dialectical aims by manoeuvring strategically when carrying out particular discussion moves of the dialectical procedure for resolving a dispute. First, attention will be paid to the ways in which praeteritio can be realized in discourse. Next, an analysis is given of the effects the use of praeteritio may have as a result of the presentational means that are employed. This analysis will be used to establish the possibilities for strategic manoeuvring with this device in the different stages of an argumentative discussion. Finally, an indication is given of how the types of strategic manoeuvring that a praeteritio can be instrumental in may derail, and in which violations of the rules for critical discussion such derailed manoeuvrings may result.
\end{abstract}

Keywords Evasion of the burden of proof - Paralipsis - Praeteritio . Reticence $\cdot$ Strategic manoeuvring

\section{Introduction}

In this paper, the stylistic device of praeteritio will be discussed by making use of the theoretical framework that Frans van Eemeren and Peter Houtlosser have been developing during the last 10 years, as they have integrated rhetorical insight into the pragma-dialectical approach to argumentation. In van Eemeren and Houtlosser's view, there is a rhetorical as well as a dialectical dimension to ordinary argumentative practice (2002: 9). Arguers generally do not just aim to win the discussion, but also to conduct the discussion in a reasonable way - that is, in a way

\footnotetext{
A. F. Snoeck Henkemans $(\bowtie)$

Department of Speech Communication, Argumentation Theory and Rhetoric, University of Amsterdam, Spuistraat 134, 1012 VB Amsterdam, The Netherlands e-mail: a.f.snoeckhenkemans@uva.nl
} 
that accords with the standards of a critical discussion (2002: 135). Van Eemeren and Houtlosser maintain there is no reason to assume that the rhetorical norm of persuasion is necessarily inconsistent with the critical ideal of reasonableness. Nonetheless, there is a potential tension involved in simultaneously pursuing a dialectical as well as a rhetorical aim (2002: 135). In order to diminish this tension, arguers make use of what van Eemeren and Houtlosser call 'strategic manoeuvring'. Strategic manoeuvring consists of three aspects that are to a large extent comparable with Perelman and Olbrechts-Tyteca's (1969) notions of 'choice', 'communion' and 'presence':

Strategic manoeuvring can take place in making an expedient choice from the options constituting the 'topical potential' associated with a particular discussion stage, in selecting a responsive adaptation to 'audience demand,' and in exploiting the appropriate 'presentational devices.' Both parties may be expected to select the material they can handle well, or that suits them best, develop the perspective most agreeable to their audience, and present their contributions in the most effective way (van Eemeren and Houtlosser 2002: 139).

Strategic manoeuvring can 'derail' and become fallacious if a party allows its dialectical aims to be overruled by its rhetorical aims, and the arguer violates one or more rules for critical discussion.

In my own recent research I explore the possibilities for strategic manoeuvring with specific presentational means. To this end, for each stage of an argumentative discussion, I examine the role stylistic devices such as metonymy, rhetorical questions and praeteritio can play in effectively presenting the topical choices that arguers have made. The approach taken in this research is as follows: in order to obtain more insight into the strategic potential of certain tropes and figures of thought, an analysis is given of the communicative and interactional effects these devices may have according to classical and modern stylistics; these effects are then analysed from the perspective of strategic manoeuvring.

The subject of this paper is the stylistic device of praeteritio. Praeteritio is a figure of thought by which, according to the Oxford Dictionary of English (2005), "attention is drawn to something by professing to omit it". The figure is also known as paralipsis, antiphrasis, occultatio and omissio. The Rhetorica Ad Herennium gives the following description of praeteritio:

Paralipsis [praeteritio] occurs when we say that we are passing by, or do not know, or refuse to say that which precisely now we are saying, as follows: "Your boyhood, indeed, which you dedicated to intemperance of all kinds, I would discuss, if I thought this the right time. But at present I advisedly leave that aside. This too I pass by, that the tribunes have reported you as irregular in military service. [...] Of these things I say nothing, but return to the issue in this trial. (IV, 27.37)

I shall first pay attention to the ways in which praeteritio can be realized in discourse. Next, I shall give an analysis of the effects the use of praeteritio may have as a result of the presentational means that are employed. Finally, I shall 
discuss what the possibilities for strategic manoeuvring with this device might be, and give some idea of the kinds of derailments in which the use of praeteritio can result.

The principle characteristic of praeteritio is that the speaker announces that he will omit something, but mentions it nonetheless. ${ }^{1}$ With praeteritio, speakers or writers both make clear that they are not going to give certain information and in doing so convey this information all the same. For this reason, this figure is sometimes called 'false reticence'. In order to gain more insight into the possible manifestations of praeteritio, I shall try to answer the following two questions: (1) By what means can speakers or writers make it clear that they will not convey certain information? And: (2) How do they manage to convey this information all the same?

\section{Ways of Making It Clear That One is Not Going to Say Something}

A first way for speakers or writers to make it clear that they will not speak about something or say something is to announce this intention explicitly. In example (1) such a direct approach is chosen:

(1) I will not tell you how my mother made coffee for my father every morning. (http://www.stanfordspokenword.com/poems/)

(2) "I am not saying that the pope is ignorant", says Yomakogullari, "but he has said such ugly things about Islam, that you cannot do otherwise but conclude that he does not know anything about our religion. Islam means peace." (NRC Handelsblad, November 28, 2006)

There are also more indirect ways to make it clear that one will not say something or talk about something. A speaker or writer, for instance, may point out that one or more of the felicity conditions for performing an assertive speech act are not fulfilled and thereby imply that performing the speech act in question is not possible.

Assertive speech acts have the following felicity conditions: ${ }^{2}$

- $\mathrm{S}$ believes that the proposition expressed in the assertive is true or correct (Sincerity condition)

- S believes that he can present evidence for the expressed proposition (Preparatory condition 1)

- S believes that the information contained by the proposition is in the listener's interest (new, important, etc.) (Preparatory condition 2)

\footnotetext{
${ }^{1}$ Reticentia (or aposiopesis or praecisio) is the term used for a genuine omission, that is, where a speaker fulfils his or her stated intention to omit (Usher 1965: 177). According to Usher, reticentia "can create rhetorical effect by suggesting the availability of a great mass of relevant evidence upon which the speaker does not intend to draw" (Usher 1965: 177).

2 My analysis of the felicity conditions for assertives is based on Houtlosser's (1995, 103-106) analysis of the basic type of assertives, which in turn is based on the felicity conditions formulated by Searle and Vanderveken (1985).
} 
- $\mathrm{S}$ believes he is entitled or in a position to express his commitment to the correctness of the proposition (i.e. there are no moral, legal or practical reasons or social conventions that prevent S from doing so) (Preparatory condition 3)

By denying that one of these felicity conditions is fulfilled, speakers can make it clear indirectly that they are not prepared to perform the assertive speech act for which they claim the conditions are unfulfilled. I will give some examples of how this may be done in the case of each of these four felicity conditions.

Denying that the Sincerity condition ( $S$ believes that the proposition expressed in the assertive is true or correct) is fulfilled:

(3) Bush [...] warned Congress against limiting funding for the war [...]: "I do not believe that someone is unpatriotic if they don't agree with my point of view. On the other hand, I think it's important for people to understand the consequences of not giving our troops the resources necessary to do the job." (http://www.usatoday.com/news/washington/2007-02-26-democrats-iraq)

Denying that Preparatory condition 1 ( $S$ believes that he can present evidence for the expressed proposition) is fulfilled:

(4) I have no reason to accuse CERT of doing this systematically, but its handling of the Stanford paper does raise questions. (http://www.freedom-to-tinker.com)

Denying that Preparatory condition 2 (S believes that the information contained by the proposition is in the listener's interest (new, important, etcetera)) is fulfilled:

(5) For valid reasons, in this page, the Daisy Institute chooses to be brief. For the time being, it is of no importance to elaborate and go into details in reference to how this organization has come to communicate with these advanced, compassionate, and gifted otherworldly Cosmic Ambassadors of splendour, generosity and good will, especially in this case it is not necessary to expatiate how they transmit ample short-term predictions of what they foresee in matters pertaining to discoveries and other matters with which to repeatedly surprise even the most complex or simplest of minds. (http://www.daisyinstitute.com/ predictions.htm)

Denying that Preparatory condition 3 ( $S$ believes he is entitled or in a position to express his commitment to the correctness of the proposition (i.e. there are no moral, legal or practical reasons or social conventions that prevent $S$ from doing so) is fulfilled:

(6) It would be unseemly for me to brag about their grades, so instead I shall just tell you that nobody brought home any consonants (bonald3.blogspot.com/ 2006_03_01_archive.html)

(7) In the still of the night air an odd sound is carried to me, if I had been a little more sober, I would have been able to tell you that it was the sound of a crowd. (http://www.demolitionmag.com/demolitionporter.htm) 


\section{Techniques for Masking the Inconsistency Inherent in Praeteritio}

As we have seen, it is characteristic of praeteritio that while speakers or writers announce that they will pass something over, they mention it all the same. What sorts of techniques are employed to present the information they claim they will not communicate without drawing too much attention to this inconsistency?

I think that in order to answer this question, first a further distinction needs to be made about the ways of presenting a praeteritio that I have discussed until now. On the one hand, there are cases where the speaker denies that he is committing himself to a certain proposition; and on the other hand, cases where the speaker denies that he is going to tell something, mention something or talk about something. If a speaker says that he is not saying something (as in example 2), or denies that the sincerity condition for asserting is fulfilled ("I do not believe that", as in example 3), or that the preparatory condition that the speaker has evidence for his assertion (example 4) is fulfilled, he thereby indicates that he is not prepared to commit himself to a certain proposition. ${ }^{3}$ This is different in cases where the speaker announces that he will not tell something (as in example 1) or claims that the second or third preparatory condition are not fulfilled (as in examples 5 to 7 ). The speaker then does not deny that he is prepared to commit himself to a proposition, but only denies that he is prepared (or able) to talk about something. The fact that he is committed to the proposition or propositions he is not prepared to express is then left implicit or is taken for granted. Take for instance example 6: the speaker claims that he cannot tell that it was the sound of a crowd that he hears, because he is too drunk. He is not, however, denying commitment to the fact that it is the sound of a crowd he hears.

This difference has consequences for the way in which speakers will avoid being overtly inconsistent when they say they will not say or tell something which they communicate nonetheless. If the arguer would not make any attempt at masking the inconsistency that is inherent in a praeteritio, he would produce praeteritio's of the type:

(8) I do not say that he is ill, but he is ill [not p, but p]

(9) I am not going to tell you what his illness was, which is the flu [I will not perform speech act A, which I am performing now]

Such blatant forms of inconsistency will probably not be of much help in getting the arguer's standpoint accepted by the other party. So how do arguers manage to mask these types of inconsistency?

In the first type of cases, where the speaker denies commitment to a proposition, a technique that is often used is to follow up this denial with a clause introduced by but, in which the speaker puts forward an alternative assertion, which on closer inspection amounts to the same thing in the context at hand or implies the same thing. In example 2 this technique is employed: the pope is not ignorant when he talks about Islam, but he does not know anything about Islam.

\footnotetext{
3 The preparatory condition that the speaker has evidence for his assertion is grouped together with the sincerity condition as a sub maxim under Grice's Maxim of Quality. So by indicating that either of these conditions is not fulfilled, speakers can make it clear that their assertion would not be sincere, and hence that they cannot be held committed to the proposition expressed in the assertion.
} 
In the second type of case, where the speaker indicates his unwillingness to convey certain information to the listener, there are various techniques that can be employed to camouflage the inconsistency. One way of achieving this effect is to avoid using an all-or-nothing formulation, such as saying that one will not speak of something, but instead use a formulation that allows for more gradation such as: 'I will not go into details' or 'I will not elaborate'. Since the criteria for considering something as detailed or not are to a large degree relative and subjective, it is hard to accuse someone of being too detailed when he claims he is not. In example (10) this technique has been used:

(10) I will not detail my very public argument with the guy who Valet parked my car and stole all the quarters from the ash tray who said something like, "No I didn't take your quarters there were no quarters in there when you gave me the car," and I said something like, "Yeah, right what you don't know is that I checked before I dropped it off with you and there was like two bucks in quarters in there and now they're gone and boy I wonder who took them," and how he responded with something like, "You are insane and I hate your car so go away and never come back," and then as he walked away a bunch of quarters dropped from his pocket. (http://www.pauldavidson.net/2004/03/11/ today-i-have-nothing-to-say/) ${ }^{4}$

A second possibility consists in using a construction like 'I will not tell you how'. (11) is an example:

(11) I will not tell you how the aircraft dipped and plunged through clouds for the good part of an hour while I sat whimpering in my seat, completely sober, wondering what heaven was like. (http://www.knotmag.com/?article=532-27k)

That this way of introducing the information may be an effective means of camouflaging the fact that one is providing the information one claims not to provide arises from the potential ambiguity of 'how' as a subordinating conjunction: it can either refer to the way in which something is done or can be used to introduce a statement of fact. To take an example, a sentence like.

(12) I will not tell you how Bob lost all his money at the casino.

may be used to make two different statements, (12a) and (12b):

(12a) I will not tell you in what way exactly Bob lost all his money at the casino.

(12b) I will not tell you that Bob lost all his money at the casino.

\footnotetext{
${ }^{4}$ In fact, the amount of detail provided in this example makes this an extreme kind of praeteritio in which the full details of that which one is claiming to omit are provided. This extreme kind of praeteritio is sometimes called proslepsis.
} 
If the speaker only intended to convey the information that Bob lost his money, (12) is a clear case of praeteritio of the self-defeating type: the information the speaker claims not to give is exactly the information that he does get across. But this may go unnoticed because of the ambiguity of the 'how-construction'. It is even likely that the listener will favour interpretation (12a) instead of (12b) since we may take it that he will assume that the speaker is observing Grice's cooperative principle (1975). The listener will therefore avoid ascribing an infringement of the Quality maxim to the speaker.

A third way of realizing a praeteritio without being overtly inconsistent is to use a construction that can also be used in the case of a genuine omission, such as: 'We will not talk about $X$ today' where $X$ is a noun or noun phrase, and not a full statement. (13) is an example of such a genuine omission (and thus not a praeteritio):

(13) I will not bring up the matter of the selection procedure here, since I think we had better discuss that at the staff meeting.

If the same construction is used with a noun or noun phrase that has negative or positive connotations, however, it can be used to convey exactly the information one wants to convey under the pretence of not doing so, as in example (14). If the intended audience of example (14) is not yet aware that there is a budget deficit, (14) could be a means of covertly informing the audience of that fact.

(14) We will not bring up the matter of the budget deficit here. (http://www. virtualsalt.com/rhetoric.htm)

An added advantage of this type of construction is that the information (i.e., that there is a budget deficit) is introduced as if it were already an accepted fact, something that is common knowledge, and thus does not merit any critical attention. $^{5}$

The use of a past conditional is a fourth example of how speakers or writers can make a statement or accusation while claiming that they will not make this statement without seeming inconsistent. They thereby make it clear that the nonfulfilment of a specific condition prevents them from making the statement. The statement is made nonetheless, as in example (15), but in this case it no longer seems to be addressed to the person in question, so that the speaker can deny having called his friend a liar.

(15) If you were not my friend, I would say you are a liar.

\footnotetext{
5 Schmid (2001) discusses comparable constructions with an abstract noun such as 'The fact is that' or 'The trouble is that' by means of which speakers or writers can manipulate the hearer or reader. Presuppositions are often bluffs, according to Schmid, by means of which speakers "trick their hearers into the unfounded belief that certain pieces of information do not require particular attention or even reflection, since they represent mutually shared, familiar ground anyway" (1548).
} 


\section{Potential Effects of Praeteritio}

According to the Rhetorica Ad Herennium, an important reason for using praeteritio is to get some information or evidence across without drawing attention to the fact that one is giving the information or presenting the evidence:

This figure is useful if employed in a matter which it is not pertinent to call specifically to the attention of others, because there is advantage in making only an indirect reference to it, or because the direct reference would be tedious or undignified, or cannot be made clear, or can easily be refuted. As a result, it is of greater advantage to create a suspicion by Paralipsis [praeteritio] than to insist directly on a statement that is refutable. (IV, 27.37)

Usher gives a similar analysis of the function of this figure of thought and claims that "it is being used as a medium for presenting evidence in such a way that it may be accepted by the audience in spite of its doubtful veracity or value" (1965: 175). He gives the following description of how praeteritio might work:

Occultatio [praeteritio] is thus used to present material which would, if critically examined by an alert jury, be found false or refutable. It enables a statement to be made and mentally noted by the jury in the speaker's favour; but because he seems to regard it as unnecessary for his argument or irrelevant, they do not examine it too closely. By this means, weak arguments and false evidence could be introduced with confidence under the pretence of omitting them. (176)

In this view, praeteritio is used to present information and in particular arguments in such a way that they do not receive too much attention, but reach the audience nonetheless. Perelman and Olbrechts-Tyteca's description of the use of praeteritio also emphasizes the usefulness of this figure for speakers who are afraid to use a certain argument:

The specific remedy open to a speaker who is afraid to use a particular argument is to hint at it. Too explicit use of some arguments is contrary to good taste, dangerous or even prohibited. There are arguments that can be referred to only by insinuation or allusion, or by a threat to use them. (Perelman and Olbrechts-Tyteca 1969: 487)

Praeteritio is seen by Perelman and Olbrechts-Tyteca as a type of "semirenunciation" or "pretended sacrifice" of an argument (1969: 487). According to them, "the sacrifice of the argument satisfies the proprieties, while it suggests also that the other arguments are sufficiently strong to make this one unnecessary."(1969: 487)

Other authors see praeteritio first and foremost as a way of emphasizing the allegedly omitted material. Lanham, for instance, defines praeteritio as a way of "emphasizing something by pointedly passing it over" (1991: 104). And Dupriez makes a distinction between "semi-preteritions which hardly emphasize an utterance" and "true preterition" which "is a form of pseudo-simulation, concealing the better to display" (1991: 354). 
I think that praeteritio may be a combination of emphasizing and hiding. Instead of just keeping silent about something or refraining from performing a specific speech act, speakers or writers who use praeteritio explicitly deny that they are committed to a certain proposition or explicitly announce that they will not speak of something. By denying their commitment to a proposition, the proposition in question becomes more prominent in the consciousness of the audience. As Clark (1975) observes with respect to Richard Nixon's famous "I am not a crook"statement, denials presuppose that the audience does or could believe what is being denied. ${ }^{6}$ And if a speaker claims not to bring up a certain subject, he thereby also draws attention to the speech act he is not performing, since this is normally only done in a situation where your audience expects you to perform a certain speech act, or where you yourself would have wanted to do this, but you nonetheless refrain from performing it. For this reason, denying that you are going to perform the speech act focuses the audience's attention on the fact that you could have done this or would have liked to do this.

So denying a commitment or denying that one is going to perform a certain speech act already draws the attention of the audience to the information speakers or writers claim not to provide. Subsequently, this information is given nonetheless, but is generally presented in such a way that the contradiction between what speakers claim to be doing and what they do in reality is camouflaged. It is in this way that praeteritio, when combined with specific presentation techniques, can be seen both as a form of emphasizing and of hiding.

\section{Praeteritio and Strategic Manoeuvring}

The question I would now like to address is what role praeteritio can play in an arguer's strategic manoeuvrings. In van Eemeren and Houtlosser's view, each of the dialectical stages of a critical discussion has its rhetorical analogue, and so for each stage both dialectical and rhetorical objectives can be distinguished (2002: 138). Until now, as we have seen, praeteritio has mainly been described as a useful technique for presenting arguments in such a way that they are less likely to raise particular criticisms. Praeteritio has thus been considered a device that can be used in the argumentation stage. In my opinion, praeteritio may also be functional in other stages of an argumentative discussion.

In the confrontation stage, where the dialectical aim is to externalize the difference of opinion, the rhetorical objective of the participants will be to define the difference of opinion in the way that is the most beneficial from their own perspective (van Eemeren and Houtlosser 2002: 138). Arguers will for instance present their standpoint in such a way that it becomes more difficult to attack, as in example (16). Or they will attempt to criticize the other party's standpoint in such a way that they cannot be called to account, as in example (17):

\footnotetext{
${ }^{6}$ A similar analysis is given by Ducrot (1984: 216-217), who claims that sentences containing a (polemic) negation entail a dialogue with a (silent) second "voice" that maintains the opposite viewpoint.
} 
Presenting a standpoint by means of a praeteritio:

(16) "I am not saying that the pope is ignorant", says Yomakogullari, "but he has said such ugly things about Islam, that you cannot do otherwise but conclude that he does not know anything about our religion. Islam means peace." (NRC Handelsblad, November 28, 2006)

Criticizing the other party's standpoint by means of a praeteritio:

(17) Dan: Saw "the Big Bite" sketch show on TV last night. How lame. How Unoriginal.

Joe M.: uh, Dan, it would be too easy to say "You do better" but a few people around here make their living from helping comedians get their stuff to air. I'd rather watch and support a local comedy for local people than any imported reality series. (http://www.phorums.com.au/archive/ index.php/t-33805.html-12k)

In the opening stage, where the dialectical aim is to establish an unambiguous point of departure for the discussion by coming to an agreement on the starting points, the rhetorical aim of each of the parties is to establish those starting points that best serve their own interest. Ways of achieving this are for instance to propose a starting point to the other party or to attribute a starting point to this party. ${ }^{7}$ In example (18), the latter is done by stating that something has already been accepted as a starting point:

Indicating that the other party has already accepted something as a starting point by means of a praeteritio:

(18) To me the baby boomer way to live life is to make the most of the options we now have, especially the option to work from home. I do not have to remind you that we have always done that. Once we see an opportunity and it looks good we go for it. This is just another one of those things we can choose to do. And just like you I would rather do it the easy way than the hard way. [...] Come join the baby boomer boom. Work from home. (ezinearticles.com/ ?Baby-Boomers-Work-From-Home-Is-An-Option\&id = 841077-40k-)

In the argumentation stage, the dialectical aim is to advance and criticize argumentation. The rhetorical aim of this stage is "to make the strongest case and to launch the most effective attack" (van Eemeren and Houtlosser 2002: 139). In order to do so arguers will, for instance, attempt to present their arguments in such a way that they seem as strong as possible. In example (19) one of the arguments for the standpoint "Americans should have more vacation time" is presented by means of a praeteritio. The arguer thus suggests he could come up with an even stronger

\footnotetext{
7 In van Eemeren et al. (2007: 90-92) a dialectical profile for the opening stage is presented in which it is specified which moves a participant in a critical discussion can make as part of proposing a starting point and responding to such a proposal. The types of indicators of the various moves in this stage of a discussion are also specified and discussed.
} 
argument, but does not need to do so, since without this additional argument the argumentation is strong enough already.

\section{Presenting an argument by means of a praeteritio:}

(19) Oh, to continue my constant rant with work in general....did you know that Chinese workers get an average of 3 weeks vacation a year??? I read that in an article last week; I couldn't believe it. They don't have freedom of speech, but they get more vacation than we do? [...] I just think we deserve more. The "best" country in the world can't give its employees as much vacation as China? I won't even mention the amount of vacation time Europeans receive. (tjparker.spaces.live.com/blog/cns!7BF842B4D45B5A92!1538.entry-44k-)

The dialectical aim of the concluding stage is to establish the result of the discussion: can the protagonist maintain his standpoint or can the antagonist maintain his position of doubt? The rhetorical objective of each party is to "claim victory" (van Eemeren and Houtlosser 2002: 139). In example (20) the antagonist ends the discussion by maintaining his doubt, but does so in the form of a praeteritio, possibly to make it easier to close off the discussion in his own favour without further ado, since his 'promise' gives the impression that he is being helpful (or at least it could, if the 'oops' were not added).

\section{Maintaining doubt by means of a praeteritio:}

(20) Thank you very much [t], and I promise not to mention that I disagree (oops). (http://www.physicsforums.com/showthread.php?t=237\&page=13-117k-)

I hope these examples will suffice to make it clear that the stylistic device of praeteritio can be applied by arguers in all stages of an argumentative discussion and can be analysed as contributing to arguers' strategic manoeuvrings. Although making use of a praeteritio does not necessarily result in a fallacy, there is a real possibility that strategic manoeuvres involving praeteritio may derail. Making use of the device of praeteritio can typically result in evasions of the burden of proof, as for instance in example (16), where the arguer immunizes his standpoint against criticism by claiming that the position that he is in fact defending is not the one he wants to defend. More generally, using praeteritio can be a means of violating a rule of critical discussion and getting away with it. In example (17), for instance, the arguer is in fact committing an ad hominem fallacy of the tu quoque type when he reacts critically to the other party's standpoint by remarking 'You do better', but because he introduces this reaction by means of a praeteritio, he cannot be held accountable for this fallacy. Since praeteritio is a technique in which what is said 'on record' and what is said 'off the record' can be distinguished in the analysis, it can generally speaking be a means of avoiding the responsibilities that one would have taken upon oneself if one would not have used the praeteritio.

Open Access This article is distributed under the terms of the Creative Commons Attribution Noncommercial License which permits any noncommercial use, distribution, and reproduction in any medium, provided the original author(s) and source are credited. 


\section{References}

Clark, H.H. 1975. Bridging. Theoretical issues in natural language processing. Proceedings of the 1975 workshop on theoretical issues in natural language processing. Collins cobuild English language dictionary (1988). London/Glasgow: Collins.

Ducrot, O. 1984. Le dire et le dit. Paris: Minuit.

Dupriez, B. 1991. A dictionary of literary devices. Translated and adapted by A. W. Halsall. New York/ London etc.: Harvester Wheatsheaf.

Grice, P. 1975. Logic and conversation. In Syntax and semantics III: Speech acts, ed. P. Cole and J.L. Morgan, 41-58. London: Academic Press.

Lanham, R.A. 1991. A handlist of rhetorical terms, 2nd ed. Los Angeles: University of California Press.

Perelman, Ch., and L. Olbrechts-Tyteca. 1969. The new rhetoric. A treatise on argumentation (Translation of La nouvelle rhétorique. Traité de l'argumentation. Paris: Presses Universitaires de France, 1958). Notre Dame: University of Notre Dame Press.

Rhetorica ad Herennium (trans: Caplan, H.). 1954. Cambridge: Harvard University Press.

Schmid, H.-J. 2001. Presupposition can be a bluff: How abstract nouns can be used as presupposition triggers. Journal of Pragmatics 33: 1529-1552.

Searle, J.R., and D. Vanderveken. 1985. Foundations of illocutionary logic. Cambridge: Cambridge University Press.

Usher, S. 1965. Occultatio in Cicero's speeches. The American Journal of Philology 85(342): 175-192.

van Eemeren, F.H., and P. Houtlosser. 2002. Strategic manoeuvering: Maintaining a delicate balance. In Dialectic and rhetoric: The warp and woof of argumentation analysis, ed. F.H. van Eemeren, and P. Houtlosser, 119-130. Boston: Kluwer.

van Eemeren, F.H., P. Houtlosser, and A.F. Snoeck Henkemans. 2007. Argumentative indicators in discourse. A pragma-dialectical study. Dordrecht: Springer. 